\title{
EFFECT OF BIOCHAR AUGMENTS ON VARIOUS GROWTH ATTRIBUTES OF RICE (Oryza sativa L.) IN CADMIUM CONTAMINATED SOIL
}

\author{
Devanand $^{1}$, Pramod Kumar Sharma ${ }^{1}$, Vipin Kumar ${ }^{2 *}$, Sarvajeet ${ }^{1}$ \\ ${ }^{1}$ Department of Soil Science and Agricultural Chemistry,Institute of Agricultural Sciences, Banaras Hindu University, Varanasi, U.P., India \\ ${ }^{2}$ Department of Agricultural Chemistry, Chaudhary Shivnath Singh Sandilya (P.G.) College, Machhra, Meerut, U.P., India
}

Received - April 27, 2020; Revision - May 23, 2020; Accepted - June 18, 2020

Available Online - June 25, 2020

DOI: http://dx.doi.org/10.18006/2020.8(3).253.264

KEYWORDS
Biochar
Cadmium
Growth
Quality
Rice
Yield

\begin{abstract}
Anthropic actions like quarrying, transportation, agriculture, industrial waste disposal etc. discharge inorganic pollutants in great concentrations that are toxic to natural ecosystems. Heavy metal like cadmium is a toxic metallic element that poses serious human health hazards through consumption of contaminated agricultural produces when present in high concentrations in soil. To address this problem this experiment was conducted in 2018 to study the effect of biocharon growth, yield and quality of rice (Oryza sativa) in cadmium contaminated soil in the net house. Six cadmium levels $(0,20,40,60,80$ and $100 \mathrm{mg} / \mathrm{kg})$ with and without two levels of biochar viz., @ 20 ton/ha and 40 ton/ha respectively were taken as treatment. Plant height, chlorophyll content, panicle length, number of tillers hill ${ }^{-1}$, productive tillers hill ${ }^{-1}$, grains panicle $^{-1}$, harvest index, grain yield, straw yield, protein content and protein yield in rice were recorded. Results of current study indicated that cadmium had negative impact on growth, yield and quality parameters of rice. Growth, yield and quality of rice significantly decreased with increasing doses of cadmium in soil. Results obtained from the experiments also revealed that addition of biochar significantly increased these parameters of rice. In general, the application of biochar has shown the ability to reduce the toxic effect of cadmium on growth, yield and quality of rice.
\end{abstract}

* Corresponding author

E-mail: vipinkumarssac@yahoo.com (Dr. Vipin Kumar)

Peer review under responsibility of Journal of Experimental Biology and Agricultural Sciences.

Production and Hosting by Horizon Publisher India [HPI] (http://www.horizonpublisherindia.in/).

All rights reserved.
All the articles published by Journal of Experimental Biology and Agricultural Sciences are licensed under a Creative Commons Attribution-NonCommercial 4.0 International License Based on a work at www.jebas.org.

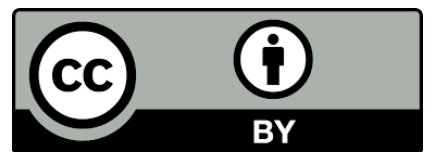




\section{Introduction}

Heavy metal contamination due to anthropogenic activities is a global problem and has multiple negative effects on soil- plant systems. This problem is becoming more severe, especially in developing countries (Bashir et al., 2017). Excessive toxic metal concentrations in the contaminated soils generally lead to soil quality degradation, crop yield reduction, and metal accumulation in agricultural products and thus pose increasing hazards to human health, as well as plants and animals (Wang et al., 2013). Remediation of these hazardous soils by conventional practices, including excavation and land filling, is unfeasible on large scale because these techniques are cost-prohibitive and environmentally disruptive (Houben et al., 2013a), they generate considerable disturbance in the environment and are economically unfeasible on a large scale (Houben et al., 2013b). Therefore to limit the solubility and the bioavailability of metal(oid)s in contaminated soil special soil-management techniques are required (Hattab et al., 2015) Metals phytoavailability and mobility in the soils can be decreases by in-situ immobilization of metals in contaminated soils using amendments (Sabir et al., 2013; Rizwan et al., 2016c; Rehman et al., 2017). For immobilization of metals in the soils, organic and inorganic amendments can be used (Chaiyarat et al., 2011) with varying benefits but organic amendments might be the better preference owing to the capacity of organic amendments to improvement in physical, chemical, biological properties and fertility status of the soil (Park et al., 2011; Kant et al., 2018a; Kant et al., 2018b). Organic amendments are very efficient to detoxify the effects of heavy metals on soil - plant systems because they are derived from raw biological waste and little pretreatment is required before their application (Park et al., 2011; Yin et al., 2016; Bashir et al., 2017). Several organic amendments can decrease the solubility, leaching and bioavailability of trace elements (Mench et al., 2010; Angelova et al., 2013; Kumar et al., 2018). Organic amendments may enhance the soil fertility and microbial activity, leading to the amelioration of the soil quality as a whole (Kumar \& Sharma, 2018). These Organic sources may be organic manures, green manure, rural wastes, crop residues, biofertilizers and vermicompost (Kumar et al., 2018; Kumar et al., 2020).

Cadmium (Cd) is one of the most harmful, toxic and wide spread heavy metal in agricultural soils (Abbas et al., 2017; Liu et al., 2020).Undoubtedly, Cd adversely affects not only the quality of agriculture products but also human health due to its high toxicity and bioavailability (Khan et al., 2018), because it is nonbiodegradable, detrimental to ecosystems and threats to human health through the food chain (Murtaza et al., 2015). Cadmium toxicity increases the oxidative stress in plants by increasing the production of reactive oxygen species (ROS) in different parts of plant. The Cd toxicity triggered the overproduction of hydrogen peroxide $\left(\mathrm{H}_{2} \mathrm{O}_{2}\right)$, electrolyte leakage, and malondialdehydecontents in plants (Gallego et al., 2012; Younis et al., 2016). Various practices such as the use of metal hyperaccumulator plants,organic and inorganic amendments and agricultural practices have been employed to remediate the Cd-contaminated soils (Qayyum et al., 2017). Among organic amendments, biochar is widely employed currently and has several benefits for soils and crops (Xu et al. 2013; Du et al. 2017; Hussain et al. 2017). Biochar (BC) is the solid organic material produced from the slow pyrolysis of waste organic materials such as manures and agricultural residues (Ok et al., 2015; Rizwanet al., 2016d), it is a carbonaceous black porous material obtained by pyrolysis of biomass under oxygen-free atmosphere (Choudhary et al., 2017). It might influence the toxicity, transport and fate of different heavy metals in the soil (Nigussie et al., 2012). Biochar has been shown to decrease the metal bioavailability in the soils and their uptake and translocation by plants (Mohamed et al., 2015; Shaheen \& Rinklebe, 2015; Li et al., 2016; Zhang et al., 2016). Biochar is a good option for heavy metal stabilization in contaminated soils, which leads to the reduced uptake of heavy metals by plants (Beesley et al. 2011; Lu et al. 2014). Use of biochar in comparison with the other chemical and biological methods in pollutant removal has remarkable potential (Zeng et al., 2015) because of its eco-friendly and economic production (Ahmad et al. 2014; Tan et al. 2015).

Rice (Oryza sativa) is the primary food for over two billion people in Asia, Africa and Latin America and has been used as a model plant in studies of cadmium toxicity and tolerance. Currently cadmium pollution in soils poses a serious threat to rice quality. Thus it is important to find ways to increase the rice tolerance to cadmium and limit their accumulation. Current experiment was conducted to address current knowledge gaps, and to investigate the effect of biochar on growth, yield and quality of rice in cadmium contaminated soil.

\section{Materials and Methods}

Current experiment was conducted in the net house condition during 2018. Six Cadmium levels (0, 20, 40, 60, 80 and 100 $\mathrm{mg} / \mathrm{kg}$ ) with and without two levels of Biochar @ 20 ton/ha and 40 ton/ha respectively were taken as a treatment. Bulk soil was taken from the Agricultural Research Farm, Institute of Agricultural Sciences, Banaras Hindu University, Varanasi. Soil was air dried gently, ground to pass through a $2 \mathrm{~mm}$ sieve and homogenized. The soil samples were analyzed for chemical properties and results are presented in table 1 . Processed $10 \mathrm{~kg}$ soil was filled in polythene lined pots. The moisture level in pots was maintained up to field capacity. Six doses of cadmium $(0,20,40$, 6080 and $100 \mathrm{mg} / \mathrm{kg}$ ) and two levels of Biochar @ 20 ton/ha and 40 ton/ha were mixed in each pot. The experiment was arranged in completely randomized design (CRD) having 18 treatments viz., Cadmium 0 ppm (Cd0), Cadmium 20 ppm (Cd20), Cadmium 40 
Table 1 Chemical characteristics of the initial experimental soil

\begin{tabular}{|c|c|c|c|}
\hline Properties & $\begin{array}{l}\text { Values of } \\
\text { initial soil }\end{array}$ & Method & Reference \\
\hline \multicolumn{4}{|c|}{ Chemical analysis } \\
\hline $\mathrm{pH}(1: 2.5)$ soil: water suspension & 7.19 & Glass electrode digital $\mathrm{pH}$ meter & Jackson (1973) \\
\hline $\begin{array}{l}\text { Electrical conductivity }\left(\mathrm{dSm}^{-1}\right) \text { at } \\
25^{0} \mathrm{C} .\end{array}$ & 0.15 & Electrical conductivity meter & Jackson (1973) \\
\hline Organic carbon (\%) & 0.25 & Wet digestion & $\begin{array}{l}\text { Walkley \& Black"s } \\
\text { (1934) }\end{array}$ \\
\hline Available $\mathrm{N}\left(\mathrm{kg} \mathrm{ha}^{-1}\right)$ & 195.70 & Alkaline permanganate method & $\begin{array}{c}\text { Subbiah \& Asija } \\
(1956)\end{array}$ \\
\hline Available $\mathrm{P}_{2} \mathrm{O}_{5}\left(\mathrm{~kg} \mathrm{ha}^{-1}\right)$ & 17.89 & 0.5M NaHCO3 Extractable & Olsen et al.(1954) \\
\hline Available $\mathrm{K}_{2} \mathrm{O}\left(\mathrm{kg} \mathrm{ha}^{-1}\right)$ & 185.78 & Flame photometer & Hanway \& Heidel (1952) \\
\hline $\begin{array}{l}\text { Available cadmium } \\
(\mathrm{ppm})\end{array}$ & 0.04 & AAS & Lindsay \& Norvell (1978) \\
\hline Available Fe (ppm) & 18.8 & AAS & Lindsay \& Norvell (1978) \\
\hline Available $\mathrm{Cu}$ (ppm) & 1.75 & AAS & Lindsay \& Norvell (1978) \\
\hline Available Mn (ppm) & 6.05 & AAS & Lindsay \& Norvell (1978) \\
\hline Available Zn (ppm) & 1.04 & AAS & Lindsay \& Norvell (1978) \\
\hline
\end{tabular}

ppm (Cd40), Cadmium 60 ppm (Cd60), Cadmium 80 ppm (Cd80), Cadmium 100ppm (Cd100), Cadmium 0 ppm + Biochar 20 (Cd0Bc20), Cadmium 0 ppm + Biochar 40 (Cd0Bc40), Cadmium 20 ppm + Biochar $20(\mathrm{Cd} 20 \mathrm{Bc} 20)$, Cadmium $20 \mathrm{ppm}+$ Biochar 40 (Cd20Bc40), Cadmium 40 ppm +Biochar 20(Cd40Bc20), Cadmium $40 \mathrm{ppm}+$ Biochar $40(\mathrm{Cd} 40 \mathrm{Bc} 40)$, Cadmium $60 \mathrm{ppm}+$ Biochar 20 (Cd60Bc20), Cadmium 60 ppm +Biochar 40 (Cd60Bc40), Cadmium $80 \mathrm{ppm}+$ Biochar $20(\mathrm{Cd} 80 \mathrm{Bc} 20)$, Cadmium $80 \mathrm{ppm}+$ Biochar 40 (Cd80Bc40), Cadmium 100ppm + Biochar 20 (Cd100Bc20)and Cadmium 100ppm + Biochar $40(\mathrm{Cd} 100 \mathrm{Bc} 40)$. Each treatment was replicated three times. Rice (var. HUR-105) was taken as a test crop in kharif season 2018. Recommended doses of $\mathrm{N}-\mathrm{P}_{2} \mathrm{O}_{5}-\mathrm{K}_{2} \mathrm{O}$ were applied @ 150:60:60 kg ha ${ }^{-1}$ through Urea, Di-ammonium phosphate, muriate of potash (MOP), respectively in all the pots.

The required amount of cadmium for $10 \mathrm{~kg}$ of soil was applied through cadmium chloride $\left(\mathrm{CdCl}_{2}\right)$ solution with six different levels of concentration like $(0,20,40,60,80,100 \mathrm{ppm})$ to the pots and allowed to keep for maintaining equilibrium. After 15 days of cadmium contamination biochar was applied @ 89.2g and $178.6 \mathrm{~g}$ pot $^{-1}$ respectively and then mix thoroughly. The biochar was collected from a private rice mill situated at Mirzapur district. Pots were incubated for next 15 days with biochar and watered at field capacity almost on a daily basis after a month of incubation (fourweek old-seedlings) was transplanted @ 5 seedlings pot ${ }^{-1}$.

The height of plants was measured with the help of meter scale from the base of the plant to the tip of the uppermost fully opened leaf. After panicle emergence, the height was measured up to the tip of the panicle. Total number of tillers hill ${ }^{-1}$ and productive tillers hill-1 ${ }^{-1}$ were counted from each pot. The numbers of leaves perplant, numbers of branches and Chlorophyll content (SPAD) were recorded from each pot and average numbers of leaves were calculated on per plant basis.
The important biometric characters such as Panicle length $(\mathrm{cm})$, Filled grains panicle ${ }^{-1}$, Panicle weight (g), 1000 grains weight or test weight (g), Grain yield (g/pot), Straw yield (g/pot) and harvest index (\%) were recorded. For quality of rice grain the protein yield is estimated with the help of protein content in rice grain.Protein content was determined on the basis of percentage of nitrogen content in rice grain and calculated as Humpshire (1956)

Protein content $=$ Nitrogen content $(\%) \times 6.25$

Protein yield (g/pot)

$$
\begin{aligned}
& =(\text { Protein content }(\%) \\
& \times \text { Yield of rice grain }(\mathrm{g} / \text { pot })) / 100
\end{aligned}
$$

For determining the significance between the treatment means and to draw valid conclusion, statistical analysis was made. The difference of the treatments mean was tested using $\mathrm{P}$ value at $1 \%$ level of probability (Gomez \& Gomez, 1984) by following the Complete Randomized Design (CRD) to draw the valid differences among the treatments.

\section{Results and Discussion}

\subsection{Effect of biochar on growth of rice crop in cadmium} contaminated soil

\subsubsection{Plant height}

The data of plant height of rice was recorded at 30 DAT, 60 DAT, and 90 DAT. The height of the rice plant in cadmium contaminated soil was observed and reported that plant height was influenced due to the toxic nature of cadmium in a treated pot which is presented in table 1.Plant height was significantly affected by different levels of cadmium at all growth stages. With an increase 
in the concentration of cadmium $(\mathrm{Cd} 0,20,40,60,80$ and 100 ppm) plant height decreased at all stages of rice crop. Decrease in the plant height might be primarily due to decline in root growth and ensuing lesser nutrient and water transport to the above part of the plant (Kumar et al., 2018).

Considerable increase in plant height was reported on 30 DAT on the addition of biochar as compared to control. Maximum plant height $71.2 \mathrm{~cm}$ was recorded in treatment $\mathrm{Cd} 0+\mathrm{Bc} 40$ followed by the treatment $\mathrm{Cd} 0+\mathrm{Bc} 20$. On the other hand, the lowest height was obtained from control pot with treatment Cd100 i.e. $46.0 \mathrm{~cm}$. The similar trend was noticed at 60 DAT and 90 DAT except a slight increase in plant height. The $\mathrm{Cd}$ is toxic to the plants and caused the reduction in growth, yield and quality of plants (Rizwan et al., 2016a). The toxic effect of cadmium disrupted the physiological responses of rice crop by altering the physiology of rice crop. The toxic effect of cadmium not only reduces plant height but it can also reduce the number of leaves and surface area of leaves per plant hence due to easily accessibility biochar in Indian context is found very promising tools in mitigating the undesirable effect of cadmium in soil. Abbas et al. (2017) reported that the plant height of wheat increased with application of biochar in a dose additive manner in soil contaminated with cadmium compared with control treatment. Khan et al. (2013) reported that the addition of Sewage Sludge Biochar significantly stimulated plant growth of rice as compared to the control. Shoot biomass, grain yield, number of tillers, and the height of tillers all increased significantly. Saengwilai et al. (2017) noticed that all rice cultivars grown in the amended soils experienced higher percent growth rates compared with the control. However, Cui et al. (2012) reported that biochar had no effect on plant growth.

\subsubsection{Chlorophy Il Content}

The data of chlorophyll was recorded by SPAD meter and is presented in table 2. Chlorophyll content increased slowly from 30 to 60 DAT and thereafter a gradual decline was observed at 90 DAT when plants move towards maturity. It is evident from the data that chlorophyll content was significantly affected by different levels of cadmium at different growth stages. Data ensured that as level of cadmium increased from 0 to $100 \mathrm{ppm}$ the amount of chlorophyll content were

Table 2 Effect of biochar on plant height and chlorophyll (SPAD) content of rice in cadmium contaminated soil

\begin{tabular}{|c|c|c|c|c|c|c|}
\hline \multirow{2}{*}{ Treatments } & \multicolumn{3}{|c|}{ Plant height } & \multicolumn{3}{|c|}{ Chlorophyll content (SPAD) } \\
\hline & $30 \mathrm{DAT}$ & $60 \mathrm{DAT}$ & $90 \mathrm{DAT}$ & $30 \mathrm{DAT}$ & $60 \mathrm{DAT}$ & $90 \mathrm{DAT}$ \\
\hline $\mathrm{Cd} 0$ & $69.3 \pm 1.98$ & $103.0 \pm 0.82$ & $105.0 \pm 0.73$ & $40.1 \pm 1.71$ & $38.2 \pm 1.63$ & $27.9 \pm 0.82$ \\
\hline $\mathrm{Cd} 20$ & $65.4 \pm 1.03$ & $98.7 \pm 0.94$ & $101.0 \pm 0.47$ & $37.5 \pm 0.82$ & $36.1 \pm 0.90$ & $25.4 \pm 1.88$ \\
\hline $\mathrm{Cd} 40$ & $60.8 \pm 1.68$ & $92.7 \pm 1.58$ & $92.8 \pm 0.80$ & $35.4 \pm 0.98$ & $34.1 \pm 1.55$ & $24.3 \pm 0.26$ \\
\hline Cd60 & $54.0 \pm 1.88$ & $89.0 \pm 0.29$ & $91.2 \pm 0.40$ & $33.1 \pm 0.90$ & $32.1 \pm 0.80$ & $22.3 \pm 0.65$ \\
\hline $\mathrm{Cd} 80$ & $48.0 \pm 0.29$ & $85.0 \pm 1.20$ & $89.0 \pm 0.43$ & $30.2 \pm 0.98$ & $29.1 \pm 0.73$ & $20.6 \pm 0.73$ \\
\hline $\mathrm{Cd} 100$ & $46.0 \pm 0.75$ & $80.0 \pm 0.74$ & $82.0 \pm 0.82$ & $28.3 \pm 1.63$ & $27.0 \pm 0.41$ & $18.6 \pm 0.62$ \\
\hline $\mathrm{Cd} 0 \mathrm{Bc} 20$ & $70.0 \pm 1.90$ & $104.0 \pm 0.81$ & $107.0 \pm 0.20$ & $41.5 \pm 0.82$ & $39.1 \pm 0.80$ & $28.6 \pm 0.57$ \\
\hline $\mathrm{Cd} 0 \mathrm{Bc} 40$ & $71.2 \pm 0.85$ & $105.0 \pm 0.13$ & $109.0 \pm 0.78$ & $42.1 \pm 0.90$ & $40.2 \pm 0.78$ & $29.5 \pm 0.82$ \\
\hline $\mathrm{Cd} 20 \mathrm{Bc} 20$ & $68.4 \pm 1.02$ & $99.9 \pm 0.81$ & $102.0 \pm 0.76$ & $38.2 \pm 0.82$ & $37.4 \pm 0.65$ & $26.2 \pm 0.73$ \\
\hline $\mathrm{Cd} 20 \mathrm{Bc} 40$ & $69.1 \pm 0.82$ & $101.0 \pm 0.78$ & $102.0 \pm 0.84$ & $39.0 \pm 0.78$ & $38.3 \pm 0.16$ & $27.2 \pm 0.78$ \\
\hline $\mathrm{Cd} 40 \mathrm{Bc} 20$ & $61.3 \pm 0.77$ & $92.7 \pm 0.42$ & $94.0 \pm 1.25$ & $36.4 \pm 0.16$ & $35.5 \pm 0.90$ & $25.4 \pm 1.63$ \\
\hline $\mathrm{Cd} 40 \mathrm{Bc} 40$ & $64.9 \pm 0.81$ & $94.0 \pm 0.82$ & $96.9 \pm 1.68$ & $37.2 \pm 0.98$ & $36.1 \pm 0.73$ & $26.1 \pm 0.82$ \\
\hline $\mathrm{Cd} 60 \mathrm{Bc} 20$ & $55.0 \pm 0.82$ & $89.8 \pm 0.20$ & $92.9 \pm 0.78$ & $34.1 \pm 0.40$ & $33.1 \pm 0.86$ & $23.2 \pm 0.16$ \\
\hline $\mathrm{Cd} 60 \mathrm{Bc} 40$ & $58.6 \pm 1.60$ & $90.0 \pm 0.81$ & $94.8 \pm 0.80$ & $35.2 \pm 0.65$ & $34.1 \pm 0.82$ & $24.3 \pm 0.98$ \\
\hline $\mathrm{Cd} 80 \mathrm{Bc} 20$ & $49.0 \pm 0.20$ & $86.0 \pm 0.86$ & $91.3 \pm 0.80$ & $31.2 \pm 0.86$ & $30.1 \pm 0.90$ & $21.1 \pm 0.78$ \\
\hline $\mathrm{Cd} 80 \mathrm{Bc} 40$ & $51.0 \pm 0.74$ & $88.3 \pm 0.83$ & $93.3 \pm 0.91$ & $33.4 \pm 0.65$ & $32.1 \pm 0.80$ & $22.0 \pm 0.78$ \\
\hline $\mathrm{Cd} 100 \mathrm{Bc} 20$ & $46.9 \pm 0.73$ & $80.9 \pm 0.82$ & $83.0 \pm 0.82$ & $29.5 \pm 1.14$ & $28.0 \pm 0.41$ & $19.1 \pm 0.40$ \\
\hline $\mathrm{Cd} 100 \mathrm{Bc} 40$ & $49.6 \pm 2.14$ & $83.6 \pm 0.43$ & $85.0 \pm 0.81$ & $30.5 \pm 0.80$ & $29.0 \pm 0.41$ & $20.2 \pm 0.82$ \\
\hline $\operatorname{SEm} \pm$ & 0.88 & 0.57 & 0.59 & 0.65 & 0.56 & 0.62 \\
\hline P value $(0.01)$ & 2.52 & 1.64 & 1.70 & 1.88 & 1.62 & 1.78 \\
\hline
\end{tabular}

Journal of Experimental Biology and Agricultural Sciences http://www.jebas.org 
decreased respectively because of oxidative stress induced by cadmium accumulation in the plant which resulted in lipid peroxidation in plants that cause severe damage to the cell membranes (Shamshad et al., 2018). The oxidative stress is induced by cadmium initiates the degradation of photosynthetic pigments which causes a decline in growth of the plant. High cadmium concentration affects photosynthesis in terms of $\mathrm{CO}_{2}$ fixation, electron transport, photophosphorylation, and enzyme activities that can disturb the chloroplast ultra-structure there by disturbing the photosynthetic process (Song et al., 2019). Under cadmium stress situation photosynthesis, chlorophyll a, chlorophyll b, carotenoids, net photosynthetic rate, stomatal conductance, transpiration rate, and water use efficiency was reported decreased in rice plant (Rascio et al. 2008). $\mathrm{Cd}$ toxicity reduced the gas exchange attributes and photosynthetic pigments and caused the destruction of chloroplast structures (Rochayati et al., 2011). Heavy metal mainly distresses chloroplast ultrastructure, causing lipid peroxidation of photosynthetic membranes, damages photosynthetic pigments and obstructs PSII activity (Chen et al., 2019). The cadmium toxicity results in growth inhibition of rice crop more or less showing chlorosis while excessive cadmium exposure $\mathrm{Cd} 100 \mathrm{mg} \mathrm{kg}^{-1}$ of soil causes leaf chlorosis and necrosis (Liu et al. 2009). Results regarding chlorophyll content after 30 days of transplantation in rice crop indicated that chlorophyll content significantly enhanced due to the application of biochar. The highest chlorophyll content was recorded 42.10 in treatment $\mathrm{Cd} 0+\mathrm{Bc} 40$ followed by treatment $\mathrm{Cd} 0 \mathrm{ppm}+\mathrm{Bc} 20(41.50)$ respectively. While plants grown on soil treated with Cd100ppm without application of biochar leads to an extreme yellowing of leaves due to lack of chlorophyll content. The application of biochar significantly increased chlorophyll content in rice crop. Liu et al. (2020) reported that the addition of organic amendments in Cd contaminated soil, increased chlorophyll contents of rice. The increase in chlorophyll contents might be due to the reversal of Cd induced toxicities in the plants with BC application (Rizwan et al., 2016b; Kumar et al., 2018).

\subsubsection{Number of tillers hill $^{-1}$}

The data of total tillers per hill and productive tillers per hill recorded and presented in table 3. Number of tillers per hill increased slowly from 30 to 60 DAT. Levels of cadmium usually affected the tiller number. As the cadmium concentration increased there was a decreased in the number of the total tillers and

Table 3 Effect of biochar on No. of tillers and productive tillers hill ${ }^{-1}$ of rice in cadmium contaminated soil

\begin{tabular}{|c|c|c|c|c|}
\hline \multirow[b]{2}{*}{ Treatments } & \multicolumn{3}{|c|}{ No. of Tillers hill ${ }^{-1}$} & \multirow{2}{*}{ Productive tillers hill ${ }^{-1}$} \\
\hline & $30 \mathrm{DAT}$ & 60 DAT & $90 \mathrm{DAT}$ & \\
\hline $\mathrm{Cd} 0$ & $7.2 \pm 0.18$ & $8.6 \pm 0.24$ & $9.6 \pm 0.45$ & $7.5 \pm 0.73$ \\
\hline $\mathrm{Cd} 20$ & $6.1 \pm 0.12$ & $8.2 \pm 0.16$ & $9.3 \pm 0.65$ & $7.2 \pm 0.91$ \\
\hline $\mathrm{Cd} 40$ & $5.2 \pm 0.13$ & $7.1 \pm 0.29$ & $8.1 \pm 0.57$ & $6.5 \pm 0.96$ \\
\hline Cd60 & $4.6 \pm 0.23$ & $6.2 \pm 0.24$ & $7.2 \pm 0.59$ & $6.0 \pm 0.62$ \\
\hline $\mathrm{Cd} 80$ & $4.2 \pm 0.24$ & $5.8 \pm 0.22$ & $6.8 \pm 0.65$ & $5.1 \pm 0.86$ \\
\hline $\mathrm{Cd} 100$ & $4.0 \pm 0.22$ & $5.2 \pm 0.28$ & $6.2 \pm 0.91$ & $4.8 \pm 0.65$ \\
\hline $\mathrm{Cd} 0 \mathrm{Bc} 20$ & $7.4 \pm 0.16$ & $9.8 \pm 0.21$ & $12.8 \pm 1.53$ & $11.2 \pm 0.88$ \\
\hline $\mathrm{Cd} 0 \mathrm{Bc} 40$ & $7.6 \pm 0.20$ & $10.2 \pm 0.29$ & $13.0 \pm 0.75$ & $11.8 \pm 0.49$ \\
\hline $\mathrm{Cd} 20 \mathrm{Bc} 20$ & $6.4 \pm 0.18$ & $8.6 \pm 0.22$ & $12.2 \pm 0.82$ & $11.0 \pm 0.82$ \\
\hline $\mathrm{Cd} 20 \mathrm{Bc} 40$ & $6.8 \pm 0.11$ & $8.9 \pm 0.33$ & $12.8 \pm 0.96$ & $11.2 \pm 0.98$ \\
\hline $\mathrm{Cd} 40 \mathrm{Bc} 20$ & $5.6 \pm 0.12$ & $8.2 \pm 0.37$ & $11.2 \pm 0.88$ & $9.50 \pm 0.57$ \\
\hline $\mathrm{Cd} 40 \mathrm{Bc} 40$ & $5.8 \pm 0.16$ & $8.6 \pm 0.43$ & $11.6 \pm 0.95$ & $9.80 \pm 0.78$ \\
\hline $\mathrm{Cd} 60 \mathrm{Bc} 20$ & $4.8 \pm 0.20$ & $7.2 \pm 0.49$ & $10.2 \pm 1.56$ & $8.20 \pm 0.75$ \\
\hline $\mathrm{Cd} 60 \mathrm{Bc} 40$ & $5.3 \pm 0.24$ & $7.6 \pm 0.41$ & $10.4 \pm 0.43$ & $8.50 \pm 0.24$ \\
\hline $\mathrm{Cd} 80 \mathrm{Bc} 20$ & $4.6 \pm 0.22$ & $6.5 \pm 0.37$ & $8.2 \pm 0.75$ & $7.10 \pm 0.94$ \\
\hline $\mathrm{Cd} 80 \mathrm{Bc} 40$ & $5.0 \pm 0.16$ & $6.7 \pm 0.54$ & $8.4 \pm 0.86$ & $7.00 \pm 0.82$ \\
\hline $\mathrm{Cd} 100 \mathrm{Bc} 20$ & $4.4 \pm 0.19$ & $5.8 \pm 0.59$ & $8.0 \pm 0.80$ & $6.60 \pm 0.70$ \\
\hline $\mathrm{Cd} 100 \mathrm{Bc} 40$ & $4.6 \pm 0.33$ & $6.2 \pm 0.70$ & $8.3 \pm 0.66$ & $6.00 \pm 0.86$ \\
\hline $\mathrm{SEm} \pm$ & 0.11 & 0.10 & 0.13 & 0.15 \\
\hline $\mathrm{P}$ value $(0.01)$ & 0.34 & 0.30 & 0.37 & 0.43 \\
\hline
\end{tabular}

Journal of Experimental Biology and Agricultural Sciences http://www.jebas.org 
productive tiller per hill. Result showed that number of tillers per hill of rice and productive tillers per hill were significantly affected due to the application of different doses of cadmium. Similar results had been reported by Ahmad et al. (2011).

The maximum total tillers count hill ${ }^{-1}$ was recorded 13.0 and productive tillers hill ${ }^{-1}$ was recorded 11.8 respectively and pot treated with biochar recorded maximum tiller count i.e. 13 in treatment $\mathrm{Cd} 0+\mathrm{Bc} 40$ followed by 12.8 in treatment $\mathrm{Cd} 0+\mathrm{Bc} 20$. While total minimum number of tiller count per hill was 6.20 and productive tillers count per hill was 4.80 both in treatment (Cd100). The effect of biochar was found significant in increasing the number of tillers per hill and productive tillers hill ${ }^{-1}$ in rice crop because it supplies the better and adequate amount of macro and micronutrient resulted in better toleration for cadmium in rice. Biochar increased soil fertility, enhancing plant growth by decreasing phyto-available fractions of metals, while cadmium toxicity restricted rice growth as estimated in terms of root and shoot length, leaf area, root area, number of leaves and roots per plant (Song et al., 2015).

The variation in the above-mentioned parameters recorded might be attributed to the availability of nutrients. Nutrient availability from organic sources is due to microbial action which is slow and steady and further through improved physical conditions of the soils (Hasanuzzaman et al., 2010). Biochar showed the better result as compared to another organic amendment because of its chemical stability as it widens the possibility of sequestering carbon besides that it also increased soil fertility and acts as a soil conditioner, application of biochar could also reduce metal uptake in various plants species and increased available nutrient uptake for the plant (Houben \& Sonnet, 2015).

\subsection{Effect of biochar on yield attributes and yields of rice in cadmium contaminated soil}

\subsubsection{Panicle length (cm)}

The length of the panicle is basically influenced by cadmium concentration along with the addition of biochar. Data collected regarding the length of panicle which is presented in table 4 revealed that plant has considerable variations and can survive with an increased in the levels of cadmium but resulted in shorter panicle length over control treatment. It is evident from the results that panicle length varied from 16.20 to $23.10 \mathrm{~cm}$ among different

Table 4 Effect of biochar on yield attributes and yields of rice crop in cadmium contaminated soil

\begin{tabular}{|c|c|c|c|c|c|c|c|}
\hline Treatments & $\begin{array}{l}\text { Panicle length } \\
(\mathrm{cm})\end{array}$ & $\begin{array}{l}\text { Total grain } \\
\text { hill }^{-1}\end{array}$ & $\begin{array}{l}\text { Unfilled grain } \\
\text { hill }^{-1}\end{array}$ & $\begin{array}{l}\text { Grain yield } \\
\text { (g/pot) }\end{array}$ & $\begin{array}{l}\text { Straw yield } \\
(\mathrm{g} / \mathrm{pot})\end{array}$ & $\begin{array}{c}\text { Harvest index } \\
(\%)\end{array}$ & $\begin{array}{l}\text { Test weight } \\
\text { (g) }\end{array}$ \\
\hline $\mathrm{Cd} 0$ & $23.1 \pm 0.78$ & $132 \pm 3.27$ & $9.00 \pm 0.82$ & $45.8 \pm 2.30$ & $50.0 \pm 0.82$ & $47.8 \pm 0.73$ & $25.0 \pm 0.82$ \\
\hline $\mathrm{Cd} 20$ & $20.6 \pm 0.98$ & $124 \pm 2.16$ & $12.0 \pm 1.63$ & $42.1 \pm 0.73$ & $48.1 \pm 0.90$ & $46.7 \pm 0.82$ & $24.0 \pm 1.22$ \\
\hline $\mathrm{Cd} 40$ & $18.3 \pm 1.63$ & $117 \pm 2.94$ & $13.0 \pm 2.16$ & $39.1 \pm 1.59$ & $46.8 \pm 1.06$ & $45.5 \pm 0.76$ & $23.0 \pm 1.47$ \\
\hline Cd60 & $17.9 \pm 0.82$ & $109 \pm 2.16$ & $15.0 \pm 1.41$ & $36.1 \pm 1.22$ & $44.5 \pm 0.73$ & $44.8 \pm 0.80$ & $22.0 \pm 1.87$ \\
\hline $\mathrm{Cd} 80$ & $17.0 \pm 0.81$ & $105 \pm 3.27$ & $17.0 \pm 1.41$ & $33.2 \pm 0.91$ & $42.3 \pm 0.65$ & $44.0 \pm 1.87$ & $21.0 \pm 2.04$ \\
\hline $\mathrm{Cd} 100$ & $16.2 \pm 1.55$ & $95 \pm 2.94$ & $19.0 \pm 1.63$ & $29.2 \pm 0.78$ & $40.2 \pm 1.76$ & $42.1 \pm 1.44$ & $20.0 \pm 2.16$ \\
\hline $\mathrm{Cd} 0 \mathrm{Bc} 20$ & $23.7 \pm 1.39$ & $136 \pm 1.63$ & $8.0 \pm 0.82$ & $46.2 \pm 1.02$ & $50.3 \pm 1.56$ & $47.9 \pm 1.50$ & $25.2 \pm 1.72$ \\
\hline $\mathrm{Cd} 0 \mathrm{Bc} 40$ & $24.9 \pm 0.82$ & $142 \pm 3.56$ & $7.0 \pm 2.16$ & $47.0 \pm 1.08$ & $50.4 \pm 1.80$ & $48.2 \pm 1.27$ & $26.7 \pm 0.81$ \\
\hline $\mathrm{Cd} 20 \mathrm{Bc} 20$ & $20.9 \pm 0.86$ & $126 \pm 2.83$ & $11.0 \pm 1.63$ & $42.7 \pm 0.90$ & $48.4 \pm 0.91$ & $46.9 \pm 1.73$ & $25.0 \pm 1.63$ \\
\hline $\mathrm{Cd} 20 \mathrm{Bc} 40$ & $22.0 \pm 1.11$ & $130 \pm 2.45$ & $9.0 \pm 0.82$ & $43.3 \pm 0.98$ & $48.9 \pm 0.78$ & $47.0 \pm 0.79$ & $25.9 \pm 2.15$ \\
\hline $\mathrm{Cd} 40 \mathrm{Bc} 20$ & $20.4 \pm 1.05$ & $125 \pm 4.08$ & $12.0 \pm 2.45$ & $39.8 \pm 0.86$ & $47.1 \pm 0.94$ & $45.8 \pm 0.87$ & $24.0 \pm 0.82$ \\
\hline $\mathrm{Cd} 40 \mathrm{Bc} 40$ & $21.1 \pm 1.63$ & $132 \pm 1.63$ & $10.0 \pm 2.45$ & $40.3 \pm 1.55$ & $47.4 \pm 1.02$ & $46.0 \pm 1.59$ & $25.2 \pm 1.51$ \\
\hline Cd60Bc20 & $18.6 \pm 0.91$ & $115 \pm 3.74$ & $14.0 \pm 2.16$ & $36.8 \pm 1.87$ & $45.0 \pm 1.63$ & $45.0 \pm 0.81$ & $22.9 \pm 1.31$ \\
\hline $\mathrm{Cd} 60 \mathrm{Bc} 40$ & $20.0 \pm 0.83$ & $120 \pm 3.30$ & $12.0 \pm 1.63$ & $37.2 \pm 1.52$ & $45.4 \pm 1.15$ & $45.0 \pm 0.84$ & $23.2 \pm 0.98$ \\
\hline $\mathrm{Cd} 80 \mathrm{Bc} 20$ & $17.8 \pm 1.23$ & $108 \pm 0.82$ & $16.0 \pm 1.41$ & $33.9 \pm 1.22$ & $42.6 \pm 0.82$ & $44.3 \pm 1.81$ & $22.1 \pm 1.59$ \\
\hline $\mathrm{Cd} 80 \mathrm{Bc} 40$ & $18.9 \pm 1.02$ & $114 \pm 3.27$ & $14.0 \pm 0.82$ & $34.1 \pm 1.51$ & $42.8 \pm 1.28$ & $44.3 \pm 1.96$ & $22.4 \pm 1.10$ \\
\hline $\mathrm{Cd} 100 \mathrm{Bc} 20$ & $17.4 \pm 1.07$ & $98 \pm 2.94$ & $18.0 \pm 2.16$ & $29.8 \pm 1.43$ & $40.6 \pm 1.42$ & $42.3 \pm 1.63$ & $21.9 \pm 1.42$ \\
\hline $\mathrm{Cd} 100 \mathrm{Bc} 40$ & $17.9 \pm 1.17$ & $102 \pm 1.63$ & $16.0 \pm 1.63$ & $30.2 \pm 1.67$ & $40.9 \pm 1.22$ & $42.5 \pm 1.22$ & $22.0 \pm 1.08$ \\
\hline $\mathrm{SEm} \pm$ & 0.61 & 2.93 & 0.91 & 0.15 & 0.41 & 0.60 & 0.74 \\
\hline $\mathrm{P}$ value $(0.01)$ & 1.76 & 8.41 & 2.61 & 0.43 & 1.18 & 1.73 & 2.13 \\
\hline
\end{tabular}

Journal of Experimental Biology and Agricultural Sciences

http://www.jebas.org 
level of cadmium concentration. Maximum panicle length $24.90 \mathrm{~cm}$ was found associated with the treatment $\mathrm{Cd} 0+\mathrm{Bc} 40$ which was significantly higher due to the application of biochar followed by $\mathrm{Cd} 0+\mathrm{Bc} 20$ i.e. $23.7 \mathrm{~cm}$. Cadmium levels and biochar with respect to the length of panicle was found significant at every stage of rice crop. However, Khan et al. (2013) found that by sewage sludge biochar no significant change was observed in the panicles length of rice.

\subsubsection{Number of grains hill $^{-1}$}

There was a significant effect reflected on number of grains per panicle with different level of cadmium application presented in table 4 . The number of grains per panicle varied from 95 to 132 grain hill ${ }^{-1}$ in case of different levels of cadmium. The highest total number of grains hill ${ }^{-1}$ was observed in treatment $(\mathrm{Cd} 0+\mathrm{Bc} 40)$ i.e. 142 followed by treatment $(\mathrm{Cd} 0+\mathrm{Bc} 20)$ i.e. 136 . Result of study revealed that there was a decreased in grains per panicle from 130 in $\mathrm{Cd} 20+\mathrm{Bc} 40$ to 98 in $\mathrm{Cd} 100+\mathrm{Bc} 20$ as the concentration of cadmium increased. It was reported that cadmium could transfer from root of rice crop to grains by the mechanism of translocation and decreases grain yield, quality, and nutrient uptake by rice crop (Rodda et al., 2011).

\subsubsection{0 grains weight $(\mathrm{g})$ or test weight}

Cadmium levels and application of biochar may influence weight of rice grain at reproductive stage that has been presented in table 4 . Data revealed that 1000 grains weight varies from $26.6 \mathrm{~g}$ in $\mathrm{Cd} 0 \mathrm{Bc} 40$ to $20 \mathrm{~g}$ in treatment $\mathrm{Cd} 100$. Data reflected that, increased in cadmium content decreases the test weight in rice crop. Application of biochar can significantly influenced test weight of rice grain. Maximum weight of 1000 grains was recorded $26.6 \mathrm{~g}$ in treatment $\mathrm{Cd} 0+\mathrm{Bc} 40$ followed by treatment $\mathrm{Cd} 0+\mathrm{Bc} 20$ i.e. $25.2 \mathrm{~g}$ respectively.

Improving growth coupled with the transport of photosynthates towards reproductive structure might have increased yield and yield attributes due to addition of biochar. The results indicated that cadmium affected yield attributes in rice crop even though it was reported as a hyper accumulator and high tolerant crop for heavy metals. Jatav et al. (2016) showed a significant increase in test weight with application of graded level of biochar along with sewage sludge. Ganesh et al. (2015) found that chromium polluted soil mixed with organic amendments increased 1000 grain weight of paddy as compared to polluted soil without amendments.

\subsubsection{Grain yield and straw yield}

The yield of rice grain and straw has been depicted in table 4 . Cadmium directly has an adverse effect on rice yield but it can be mitigated by using an adequate amount of biochar. The lowest value of rice grain yield was $29.2 \mathrm{~g} \mathrm{pot}^{-1}$ in the treatment $\mathrm{Cd} 100$ with a reduction in the yield over $36.1 \%$ compared to the treatment of $\mathrm{Cd} 0+\mathrm{Bc} 40$ which was reported highest yield i.e. $45.7 \mathrm{~g}$. Similar results were also reported in case of the straw yield of rice because it translocated in grain through the shoot. The highest reduction in straw yield due to the direct effect of cadmium concentration observed in treatment $\mathrm{Cd} 100$ having yield $40.2 \mathrm{~g} \mathrm{pot}^{-1}$. The beneficial effect of cadmium was also seen at treatment $\mathrm{Cd} 20$ in rice crop which could be attributed to increased absorption of nutrients like $\mathrm{K}, \mathrm{Ca}$ and $\mathrm{Mg}$, at low concentration of cadmium while at very higher cadmium concentration it might have adversely affected yield attributes due to phytotoxicity. Radziemska et al. (2018) also reported negative correlation between plant yields and increasing contamination of soil with $\mathrm{Cr}$.

The straw yield of rice was enhanced due to the direct effect of biochar over control treatment. Highest straw yield was reported in treatment $\mathrm{Cd} 0+\mathrm{Bc} 40$ i.e. $50 \mathrm{~g}$ followed by $\mathrm{Cd} 0+\mathrm{Bc} 20$ i.e. $48.1 \mathrm{~g}$. The improvement in yield of rice could be attributed due to the addition of biochar to the soil, which increased the availability of nutrients due to enhancement in important soil properties. The adverse effect of cadmium on the yield of rice could be alleviated to some extent especially with biochar addition.

The role of biochar is to reduce the toxicity of cadmium by improving the efficacy of nutrient uptake which leads improvement in yield of rice crop that could be attributed due to the reduction in the bioavailability of cadmium and thus reduces toxic effects of Cadmium in the soil. Bioavailability of heavy metal in the soil is said to be the fraction of the total metal in the interstitial pure water that is available to the receptor organism. More specifically, it refers to the biologically available fraction or pool that can be taken up by an organism and can react with its metabolic machinery. By immobilization of this fraction of metals reduced its bioavailability. This could be achieved by the addition of biochar which increases the immobilization of metal through adsorption reactions, and formation of organo-cadmium complexes. The grain and straw yield has been drastically reduced due to the toxic effect of cadmium on the roots and shoots of rice crop. The characteristics of rice crop vary under various treatments of cadmium. High organic matter, macro and micronutrients enhanced soil physical, chemical, and biological properties. The decrease in biomass or productivity of rice crop was due to a disruption in nitrogen metabolism of seedlings under cadmium stress condition (Chatterjee \& Chatterjee, 2000). Increased crop yield is a commonly reported benefit of adding biochar to soils, though experimental results are variable and dependent on the experimental set-up, soil properties, and conditions (Jeffery et al., 2011).

These yield attributes like panicle number, grains panicle ${ }^{-1}$ test weight, increased with the addition of biochar compared to control treatment. Biochar significantly increased grain yield in case of 
rice and grain yield sustained over 3 years after using a single dose of soil amendment like wheat straw or biochar (Khan et al., 2013). Further, Nagaraju et al. (2015) stated that heavy metals are carcinogenic in nature, damage DNA, proteins and lipids that adversely affect plant growth and yield. Senthilraja (2017) accentuated that the adding of amendments in combination with brewery wastewater irrigation significantly enhanced the yield attributes of sesame. Kumar et al. (2020) revealed that yield of mustard significantly increased with application of organic amendments in soil contaminated with $\mathrm{Cr}$.

The ability of organic amendments to increase the yield was attributed to the combined effect of increased nutrient availability ( $\mathrm{P}$ and $\mathrm{N}$ ) and improved soil chemical conditions upon amendment (Hossain et al., 2010). Increase in seed and stalk yield by amendment possibly will be because of favorable influence of organic manures which enriched fertility and soil physical environment that might have sustained better germination, root proliferation, nutrient and water uptake (Senthilraja, 2017). Shaheen et al. (2017) explained that the highest yield of crops in contaminated soils at the compost treatment might be due to supplying the soil with nutrients such as carbon, nitrogen and phosphorus. Ramzani et al. (2016) cleared that enhanced plant growth and grain yield in rice crop can be attributed to the positive effect of biochar. Maximum crop yield in contaminated soils might be due to furnishing the soil with nutrients such as carbon, nitrogen, and phosphorus by the amendment (Shaheen et al., 2017; Kumar et al., 2020). Higher chlorophyll levels often resulted in higher crop yields because chlorophylls participate in energy creation and conversion via photosynthesis for crop growth (Alam et al., 2019).

\subsubsection{Harvest index (\%)}

Harvest index of rice was affected by different concentration of cadmium and biochar applied in experimental soil that has been presented in table 4. Data regarding harvesting index revealed that (H.I) varied from $48.2 \%$ to $42.01 \%$. However, the highest harvest index recorded in treatment $\mathrm{Cd} 0+\mathrm{Bc} 40$ was $48.2 \%$ followed by the treatment $\mathrm{Cd} 0+\mathrm{bc} 20$ i.e. $47.2 \%$ and lowest harvest index was reported in treatment $\mathrm{Cd} 100$ i.e. $42.01 \%$. Biochar significantly influenced the yield of rice and hence interaction effect of biochar regarding to harvest index was found significantly higher. Malaviya \& Sharma (2011) stated that decrease in harvest index with the increase in effluent concentration signifying the fact that seed weight was more sensitive to the applied effluent stress than straw weight. Kakar et al. (2010) found that harvest index was higher in plants from control compared with rest of the effluents treatments.

Harvest index denotes the proportion of economically produced part to the above ground biomass (Yadav, 2016). Harvest index varied significantly with application of organic amendments. The significant effect suggests that plants maintained a higher supply of photosynthates to reproductive part as compared to vegetative biomass to sustain higher index (Latare, 2014).

\subsection{Effect of biochar on quality of rice grain in cadmium contaminated soil}

\subsubsection{Protein content and Protein yield in rice grain}

Data regarding protein content and yield is shown in figure 1 . The highest protein $(8.75 \%)$ content recorded in treatment $\mathrm{Cd} 0+\mathrm{Bc} 40$ this was followed by $8.62 \%$ in treatment $\mathrm{Cd} 0+\mathrm{Bc} 20$. While the lowest protein content $6.12 \%$ was recorded at highest dose of cadmium. The interaction between biochar and protein content found significant in rice crop. As cadmium level increased in soil then protein content decreased in all treatments while biochar application increased the protein content in rice crop and reduced the toxic effect of cadmium. Similar trend was observed in case of protein yield.

Excess of cadmium accumulation by the plant not only have negative effects on the quality of foods grain, but it also reduces the growth, chlorophyll content and yield through a different mechanism such as the reduction in nutrient uptake, photosynthesis, and over production of reactive oxygen species which can alter the physiology of plant and hence reported a drastic reduction of quality and quantity food grain production (Nagajyoti et al., 2010). The excess Cd decreased the uptake of macro- and micronutrients by plants, which deteriorated the quality of the food crops (Rochayati et al., 2011). Gao et al. (2016) and Rehman et al. (2017) reported that cadmium negatively affects rice growth and quality in the number of cultivars. Nagaraju et al. (2015) stated that heavy metals are carcinogenic in nature, damage DNA, proteins and lipids that adversely affect plant growth and yield.

Increase in proteins with the biochar application under $\mathrm{Cd}$ stress might be due to the increase in the formation of metal-binding complexes (Younis et al., 2016). Sunitha et al. (2014) observed significant increase in crude protein content in maize (Zea mays L.) due to the application of poultry manure or vermicompost with and without microbial strains in soil contaminated with tannery wastes.

\section{Conclusion}

Results indicated that cadmium had negative impact on rice. Plant height, chlorophyll content, panicle length, number of tillers hill ${ }^{-1}$, productive tillers hill ${ }^{-1}$, grains panicle ${ }^{-1}$, harvest index, grain yield, straw yield, protein content and protein yield decreased with increasing doses of cadmium in soil i.e., $(0,20,40,60,80,100$ $\mathrm{ppm})$. The addition of biochar significantly increased these 
parameters of rice. The application of biochar reduced cadmium toxicity to some extent but not completely. Biomass of rice crop decreased with increasing doses of cadmium. The addition of biochar had significantly increased the biomass of rice and their interaction found significant. The results showed that biomass of rice plant decreased in both amended with biochar and nonamended soils upon an increase in cadmium concentration.

\section{Conflict of Interest}

All the authors hereby declare that there is no conflict of interest regarding the publication of this article.

\section{References}

Abbas T, Rizwan M, Ali S, Rehman MZ, Qayyum MF, Abbas F, Hannan F, Rinklebe J, Ok YS (2017) Effect of biochar on cadmium bioavailability and uptake in wheat (Triticumaestivum L.) grown in a soil with aged contamination. Ecotoxicology and Environmental Safety 140: 37-47

Ahmad HR, Ghafoor A, Corwin DL, Aziz MA, Saifullah SM (2011) Organic and inorganic amendments affect soil concentration and accumulation of cadmium and lead in wheat in calcareous alkaline soils. Communications in Soil Science and Plant Analysis 42:111-122

Ahmad M, Rajapaksha AU, Lim JE, Zhang M, Bolan N, Mohan D, Vithanage M, Lee SS, Ok YS (2014) Biochar as a sorbent for contaminant management in soil and water: a review. Chemosphere 99: 19-23

Alam MZ, McGee R, Hoque MA, Ahammed GJ, Boggs LC(2019) Effect of arbuscular mycorrhizal fungi, selenium and biochar on photosynthetic pigments and antioxidant enzyme activity under arsenic stress in mung bean(vigna radiata). Frontiers in Physiology 10: 193

Angelova VR, Akova VI, Artinova, NS, Ivanov KI (2013) The effect of organic amendments on soil chemical characteristics Bulgarian Journal of Agricultural Science 19: 958-971

Bashir S, Hussain Q, Akmal M, Riaz M, Hu H, Ijaz SS, Iqbal M, Abro S, Mehmood S, Ahmad M (2017) Sugarcane bagasse-derived biochar reduces the cadmium and chromium bioavailability to mash bean and enhances the microbial activity in contaminated soil. Journal of Soils and Sediments DOI 10.1007/s11368-017-1796-Z

Beesley L, Moreno JE, Clemente R, Lepp N, Dickinson N (2011) Mobility of arsenic, cadmium and zinc in a multi-element contaminated soil profile assessed by in-situ soil pore water sampling, column leaching and sequential extraction. Environmental Pollution 158:155-160
Chaiyarat R, Suebsima R, Putwattana N, Kruatrachue M, Pokethitiyook P (2011) Effects of soil amendments on growth and metal uptake by Ocimum gratissimum grown in $\mathrm{cd} / \mathrm{Zn}$ contaminated soil. Water, Air and Soil Pollution 214: 383-392

Chatterjee J, Chatterjee C (2000) Phytotoxicity of cobalt, chromium and copper in cauliflower, Environmental Pollution 109(1):69-74

Chen YE, Wu N, Zhang ZW,Yuan M, Yuan S (2019)Perspective of Monitoring HeavyMetals by Moss Visible Chlorophyll Fluorescence Parameters. Frontiers in Plant Science 10: 35doi: $10.3389 /$ fpls.2019.00035

Choudhary B, Paul D, Singh A, Gupta T (2017) Removal of hexavalent chromium upon interaction with biochar under acidic conditions: mechanistic insights and application. Environmental Science and Pollution Research 24:16786-16797

Cui L, Pan G, Li L, Yan J, Zhang A, Bian R,Chang A (2012) The reduction of wheat $\mathrm{Cd}$ uptake in contaminated soil via biochar amendment: A two-year field experiment. Bioresources 7(4): $5666-5676$

Du ZL, Zhao JK, Wang YD, Zhang QZ (2017) Biochar addition drives soil aggregation and carbon sequestration in aggregate fractions from an intensive agricultural system. Journal of Soils and Sediments 17(3):581-589

Gallego SM, Pena LB, Barcia RA, Azpilicueta CE, Iannone MF, Rosales EP, Benavides MP(2012)Unravelling cadmium toxicity and tolerance in plants: insight into regulatory mechanisms. Environmental and Experimental Botany 83: 33-46

Ganesh KS, Sundaramoorthy P, Nagarajan M (2015) Organic Soil Amendments: Potential Source for Heavy Metal Accumulation. World Scientific News 16: 28-39

Gao L, Chang J, Chen R, Li H, Lu H, Tao L, Xiong J (2016) Comparison on cellular mechanisms of iron and cadmium accumulation in rice: prospects for Cultivating Fe-rich but Cd-free Rice. Rice 9(1): 39

Gomez AK, Gomez AA (1984) Statistical procedures for Agricultural Research.Second Edition, John Wiley and Sons, New York. U.S.A.

Hanway JJ, Heidel H (1952) Soil analysis methods as used in Iowa state college soil testing laboratory. Iowa Agriculture 57: 1-31

Hasanuzzaman M, Ahamed KU, Rahmatullah NM, Akhter N, Nahar K, Rahman M.L (2010) Plant growth characters and productivity of wetland rice (Oryza sativa L.) as affected by 
application of different manures. Emirates Journal of Food and Agriculture 22: 46-58

Hattab N, Heino MM, Faure O, Bouchardon JL (2015) Effect of fresh and mature organic amendments on the phytoremediation of Technosols contaminated with high concentrations of trace elements. Journal of Environmental Management159: 37-47

Hossain MK, Strezov V, Chan KY, Nelson PF (2010) Agronomic properties of wastewater sludge biochar and bioavailability of metals in production of cherry tomato (Lycopersicon esculentum).Chemosphere78: 1167-1171

Houben D, Sonnet P (2015) Impact of biochar and root-induced changes on metal dynamics in the rhizosphere of Agrostis capillaris and Lupinus albus. Chemosphere 139: 644-651

Houben D, Evrard L, Sonnet P (2013a) Beneficial effects of biochar application to contaminated soils on the bioavailability of $\mathrm{Cd}, \mathrm{Pb}$ and $\mathrm{Zn}$ and the biomass production of rapeseed (Brassica napus L.). Biomass and Bioenergy 57: 196-204

Houben D, Evrard L,Sonnet P (2013b) Mobility, bioavailability and $\mathrm{pH}$-dependent leaching of cadmium, zinc and lead in a contaminated soil amended with biochar. Chemosphere92: 1450-1457

Humpshire EC (1956) Mineral components and ash analysis in modern method of plant analysis, Springer, Verlg Berlin

Hussain M, Farooq M, Nawaz A, Al-Sadi AM, Solaiman ZM, Alghamdi SS, Ammara U, Ok YS, Siddique KHM (2017) Biochar for crop production: potential benefits and risks. Journal of Soils and Sediments 17:685-716

Jackson ML (1973)Soil chemical analysis. Prentice- Hall of India Pvt. Limited, New Delhi, India

Jatav HS, Singh SK, Singh YV, Paul A, Kumar V, Singh P,Jayant H (2016) Effect of Biochar on Yield and Heavy Metals Uptake in Rice Grown on Soil Amended with Sewage Sludge. Journal of Pure and Applied Microbiology 10(2): 1367-1377

Jeffery S, Verheijen FGA, van der Velde M, Bastos AC (2011) A quantitative review of the effects of biochar application to soils on crop productivity using meta-analysis. Agriculture, Ecosystems and Environment 144(1): 175-187

Kakar S, Wahid A, Tareen RB, Kakar SA, Tariq M, Kayani SA (2010) Impact of municipal waste water of Quetta city on biomass, physiology and yield of canola (Brassica napus L.). Pakistan Journal of Botany 42: 317-328

Kant S, Sharma PK, Kumar V, Kumar A(2018a) Chelating compounds influence the chemical properties of post-harvest chromium contaminated soil after maize and mustard. International Journal of Chemical Studies 6: 1672-1680

Kant S, Sharma PK, Kumar V (2018b) Effect of chelating compounds on growth of maize and mustard in chromium contaminated soil. Journal of Pharmacognosy and Phytochemistry 7: 2964-2972

Khan MA, Khan S, Ding X, Khan A, Alam M (2018) The effects of biochar and rice husk on adsorption and desorption of cadmium on to soils with different water conditions (upland and saturated). Chemosphere 193: 1120-1126

Khan S, Chao C, Waqas M, Arp HPH,Zhu YG (2013) Sewage sludge biochar influence upon Rice (Oryza sativa L) yield, metal bioaccumulation and greenhouse gas emissions from acidic paddy soil. Environmental Science and Technology47: 8624-8632

Kumar V, Sharma PK(2018) Augmentation of nitrogen and phosphorous mineralization in chromium contaminated soils using organic amendments. International Journal of Chemical Studies 6: 3417-3422.

Kumar V, Sharma PK, Kant S,Shikha, Rai A, Kumar A(2018) Organic amendments influence mustard (Brassica juncea) growth in chromium contaminated soils. Journal of Pharmacognosy and Phytochemistry 7: 2026-2038.

Kumar V, Sharma PK, Jatav HS, Singh SK, Rai A, Kant S,Kumar A(2020) Organic Amendments Application Increases Yield and Nutrient Uptake of Mustard (Brassica Juncea) Grown in Chromium-Contaminated Soils. Communications in Soil Science and Plant Analysis 51(1): 149-159

Latare AM (2014) Direct and residual effect of sewage sludge on yield, availability of heavy metals and soil fertility in rice-wheat cropping system. Ph. D. Thesis submitted to Banaras Hindu University, India

Li H, Ye X, Geng Z, Zhou H, Guo X, Zhang Y, Zhao H, Wang $G(2016)$ The influence of biochar type on long-term stabilization for $\mathrm{Cd}$ and $\mathrm{Cu}$ in contaminated paddy soils. Journal of Hazardous Materials 304: 40-48

Lindsay WL, Norvell WA (1978) Development of DTPA soil test for zinc, iron, manganese and copper. Soil Science Society of American Journal 42: 421-428

Liu L, Hansong C, Peng C, Wei L, Qiaoyun H (2009) Immobilization and phytotoxicity of $\mathrm{Cd}$ in contaminated soil amended with chicken manure compost. Journal of Hazardous Materials 163(2-3): 563-567 
Liu N, Jiang Z, Li X, Liu H, Li N, Wei S (2020) Mitigation of rice cadmium (Cd) accumulation by joint application of organic amendments and selenium (Se) in high-Cd-contaminated soils. Chemosphere 241: 125106

Lu K, Yang X, Shen J, Robinson B, Huang H, Liu D, Bolan N, Pei J, Wang H (2014) Effect of bamboo and rice straw biochars on the bioavailability of $\mathrm{Cd}, \mathrm{Cu}, \mathrm{Pb}$ and $\mathrm{Zn}$ to Sedum plumbizincicola. Agriculture, Ecosystems and Environment191:124-132

Malaviya P,Sharma A (2011) Effect of distillery effluent on yield attributes of Brassica napus L. Journal of Environmental Biology32: 385-389

Mench M, Bert V, Schwitzguebel JP, Lepp N, Schröder P, Gawronski S,Vangronsveld J (2010) Successes and limitations of phytotechnologies at field scale: Outcomes, assessment and outlook from COST Action 859. Journal of Soils and Sediments 10: $1039-1070$

Mohamed I, Zhang GS, Li ZG, Liu Y, Chen F, Dai K (2015) Ecological restoration of an acidic $\mathrm{Cd}$ contaminated soil using bamboo biochar application.Ecological Engineering 84: 67-76

Murtaza G, Javed W, Hussain A, Wahid A, Murtaza B, Owens $\mathrm{G}(2015)$ Metal uptake via phosphate fertilizer and city sewage in cereal and legume crops in Zea mays Pakistan. Environmental Science and Pollution Research 22: 9136-9147

Nagajyoti PC, Lee KD, Sreekanth TVM (2010) Heavy metal occurrence and toxicity forplants. Environmental chemistry letters 8(3): 199-216

Nagaraju M, Kumar SA, Rao DM (2015) Constitutive Effects of Distinct Heavy Metals ( $\mathrm{Cd}, \mathrm{Pb}$ and $\mathrm{As}$ ) on Seed Germination and Physiological Characters of Groundnut (ArachishypogaeaL.). International Journal of Advanced Research 3(8): 959-970

Nigussie A, Kissi E, Misganaw M, Ambaw G (2012) Effect of Biochar Application on Soil Properties and Nutrient Uptake of Lettuces (Lactucasativa) Grown in Chromium Polluted Soils. American-Eurasian Journal of Agricultural \& Environmental Sciences 12(3): 369-376

Ok YS, Chang SX, Gao B, Chung HJ(2015) SMART biochar technology-A shifting paradigm towards advanced materials and healthcare research. Environmental Technology \& Innovation4: 206-209

OlsenSR, Cole CV, Watanabe FS, Dean LA (1954)Estimation of available phosphorous in soils by extraction with sodium bicarbonate. Circular United State Department of Agriculture 939: 19
Park JH, Lamb D, Paneerselvam P, Choppala G, Bolan N, Chung JW (2011) Role of organic amendments on enhanced bioremediation of heavy metal (loid) contaminated soils. Journal of Hazardous Materials 185(2): 549-574

Qayyum MF, Rehman MZ, Ali S, Rizwan M, Naeem A, Maqsood MA, Khalid H, Rinklebe J, Ok YS (2017) Residual effects of monoammonium phosphate, gypsum and elemental sulfur on cadmium phytoavailability and translocation from soil to wheat in an effluent irrigated field. Chemosphere 174: 515-523

Radziemska M, Koda E, Bilgin A,Vaverkova MD (2018) Concept of aided phytostabilization of contaminatedsoils in postindustrial areas. International Journal of Environmental Research and Public Health 15:24

Ramzani PMA, Khan WD, Iqbal M, Kausar S, Ali S, Rizwan M, Virk ZA (2016) Effect of different amendments on rice (Oryza sativa L.) growth, yield, nutrient uptake and grain quality in Nicontaminated soil. Environmental Science and Pollution Research 23(18): 18585-18595

Rascio N, Dalla Vecchia F, La Rocca N, Barbato R, Pagliano C, Raviolo M, Gonnelli C, Gabbrielli R (2008) Metal accumulation and damage in rice (cv. Vialonenano) seedlings exposed to cadmium. Environmental and Experimental Botany 62: 267-278

Rehman MZ, Khalid H, Akmal F, Ali S, Rizwan M, Qayyum MF, Iqbal M, Khalid MU, Azhar M (2017) Effect of limestone, lignite and biochar applied alone and combined on cadmium uptake in wheat and rice under rotation in an effluent irrigated field. Environmental Pollution 227:560-568

Rizwan M, Meunier JD, Davidian JC, Pokrovsky OS, Bovet N, Keller C(2016d) Silicon alleviates Cd stress of wheat seedlings (Triticum turgidum L. cv. Claudio) grown in hydroponics. Environmental Science and Pollution Research 23: 1414-1427

Rizwan M, Ali S, Adrees M, Rizvi H, Rehman MZ, Hannan F, Qayyum MF, Hafeez F, OK YS (2016b) Cadmium stress in rice: toxic effects, tolerance mechanisms and management: a critical review. Environmental Science and Pollution Research 23: 1785917879

Rizwan M, Ali S, Abbas T, Rehman MZ, Hannan F, Keller C, AlWabel MI, Ok YS(2016a) Cadmium minimization in wheat: a critical review. Ecotoxicology and Environmental Safety130: 4353

Rizwan M, Ali S, Qayyum MF, Ibrahim M, Rehman MZ, Abbas T,OK YS(2016c) Mechanisms of biochar-mediated alleviation of toxicity of trace elements in plants: a critical review. Environmental Science and Pollution Research 23:2230-2248 
Rochayati S, Du Laing G, Rinklebe J, Meissner R, Verloo M (2011) Use of reactive phosphate rocks as fertilizer on acid upland soils in Indonesia: accumulation of cadmium and zinc in soils and shoots of maize plants. Journal of Plant Nutrition and Soil Science 174: 186-194

Rodda N, Salukazana L, Jackson SAF, Smith MT (2011) Use of domestic greywater for small-scale irrigation of food crops: Effects on plants and soil. Physics and Chemistry of the Earth 36: 1051-1062

Sabir M, Hanafi MM, Aziz T, Ahmad HR, Rehman MZ, Saifullah, Murtaza G, Hakeem KR (2013) Comparative effect of activated carbon, press mud and poultry manure on immobilization and concentration of metals in maize (Zea mays) grown on contaminated soil. International Journal of Agriculture \& Biology 15(3): 559-564

Saengwilai P, Meeinkuirt W, Pichtel J, Koedrith P (2017) Influence of amendments on $\mathrm{Cd}$ and $\mathrm{Zn}$ uptake and accumulation in rice (Oryza sativa L.) in contaminated soil. Environmental Science and Pollution Research 24(18): 15756-15767

Senthilraja K (2017) Effect of Brewery Effluent Irrigation and Sludge Application in Combination with Organic Amendments on Growth and Yield of Sesame (Sesamum indicum L.). International Journal of Current Microbiology and Applied Sciences 6(12): 965-977

Shaheen SM, Balbaa AA, Khatab AM, Rinklebe J (2017) Compost and sulfur affect the mobilization and phytoavailability of $\mathrm{Cd}$ and $\mathrm{Ni}$ to sorghum and barnyard grass in a spiked fluvial soil. Environmental Geochemistry and Health 39(6): 1305-1324

Shaheen SM, Rinklebe J (2015) Impact of emerging and low cost alternative amendments on the (im) mobilization and phytoavailability of $\mathrm{Cd}$ and $\mathrm{Pb}$ in a contaminated floodplain soil.Ecological Engineering 74: 319-326

Shamshad S, Shahid M, Rafiq M, Khalid S, Dumat C, Sabir M, Murtaza B, Farooq ABU, Shah NS (2018) Effect of organic amendments on cadmium stress to pea: A multivariate comparison of germinating vs young seedlings and younger vs older leaves. Ecotoxicology and Environmental Safety 151: 91-97

Song WE, Chen SB, Liu JF, Chen LI, Song NN, Ning LI, Bin LIU (2015) Variation of cadmium concentration in various rice cultivars and derivation of cadmium toxicity thresholds for paddy soil by species-sensitivity distribution. Journal of Integrative Agriculture 14(9): 1845-1854

Song X, Yue X, Chen W, Jiang H, Han Y, Li X (2019) Detection of Cadmium Risk to the Photosynthetic Performance of Hybrid Pennisetum. Frontiers in Plant Science 10: 798 doi: 10.3389/fpls.2019.00798
Subbiah B, Asija GL (1956) A rapid procedure for estimation of available nitrogen in soil. Current Science 25(8): 259-260

Sunitha R, Mahimairaja S, Bharani A, Gayathri P (2014) Enhanced Phytoremediation Technology for Chromium contaminated Soils using Biological Amendments. International Journal of Science and Technology 3(3): 153-162

Tan X, Liu Y, Zeng G, Wang X, Hu X, Gu Y, Yang Z (2015) Application of biochar for the removal of pollutants from aqueous solutions. Chemosphere 125:70-85

Walkley A, Black CA (1934) Estimation of organic carbon by chromic acid and titration method. Soil Science 37(1): 28-29

Wang FY, Shi ZY, Xu XF, Wang XG, Li YJ (2013) Contribution of AM inoculation and cattle manure to lead and cadmium phytoremediation by tobacco plants. Environmental Science: Processes \& Impacts 15: 794-801

Xu X, Cao X, Zhao L, Wang H, Yu H, Gao B (2013) Removal of $\mathrm{Cu}, \mathrm{Zn}$, and $\mathrm{Cd}$ from aqueous solutions by the dairy manurederived biochar. Environmental Science and Pollution Research 20:358-368

Yin B, Zhou L, Yin B, Chen L (2016) Effects of organic amendments on rice (Oryza sativa L.) growth and uptake of heavy metals in contaminated soil.Journal of Soils and Sediments 16:537-546

Yadav SN (2016) Evaluation of Extractants, Critical Limit of Boron and its Response to Mustard (Brassica JunceaL.) in Inceptisols of Varanasi. Ph. D. Thesis submitted to the Banaras Hindu University, India

Younis U, Malik SA, Rizwan M, Qayyum MF, Ok YS, Shah MHR, Rehman RA, Ahmad N, (2016) Biochar enhances the cadmium tolerance in spinach (Spinacia oleracea) through modification of $\mathrm{Cd}$ uptake and physiological and biochemical attributes. Environmental Science and Pollution Research 23: 21385-21394

Zeng G, Wu H, Liang J, Guo S, Huang L, Xu P, Liu Y, Yuan Y, He X, He Y (2015) Efficiency of biochar and compost (or composting) combined amendments for reducing $\mathrm{Cd}, \mathrm{Cu}, \mathrm{Zn}$ and $\mathrm{Pb}$ bioavailability, mobility and ecological risk in wetland soil. RSC Advances5: 34541-34548

Zhang Y, Chen $\mathrm{T}$, Liao $\mathrm{Y}$, Reid BJ, Chi H, Hou Y, Cai $\mathrm{C}(2016)$ Modest amendment of sewage sludge biochar to reduce the accumulation of cadmium into rice (Oryza sativa L.): a field study. Environmental Pollution 216: 819-825 